\title{
Adaptive Evolution of Industrial Brewer's Yeast Strains towards a Snowflake Phenotype
}

\author{
Yeseren Kayacan ${ }^{1,2, \dagger}$, Thijs Van Mieghem ${ }^{1,2,+}$, Filip Delvaux ${ }^{3}$, Freddy R. Delvaux ${ }^{3}$ and \\ Ronnie Willaert $1,2,4, *$ (D) \\ 1 Alliance Research Group VUB-UGent NanoMicrobiology (NAMI), Research Group Structural Biology, \\ 1050 Brussels, Belgium; Yeseren.Kayacan@vub.be (Y.K.); thijs.van.mieghem@hotmail.com (T.V.M.) \\ 2 International Joint Research Group VUB-EPFL NanoBiotechnology \& NanoMedicine (NANO), \\ Vrije Universiteit Brussel, 1050 Brussels, Belgium \\ 3 Biercentrum Delvaux, 3040 Neerijse, Belgium; filip@biercentrum.be (F.D.); \\ Freddy.Delvaux@biw.kuleuven.be (F.R.D.) \\ 4 Department Bioscience Engineering, University Antwerp, 2020 Antwerp, Belgium \\ * Correspondence: Ronnie.Willaert@vub.be; Tel.: +32-2629-1846 \\ + These authors contributed equally to this work.
}

Received: 10 January 2020; Accepted: 3 February 2020; Published: 5 February 2020

\begin{abstract}
Flocculation or cell aggregation is a well-appreciated characteristic of industrial brewer's strains, since it allows removal of the cells from the beer in a cost-efficient and environmentally-friendly manner. However, many industrial strains are non-flocculent and genetic interference to increase the flocculation characteristics are not appreciated by the consumers. We applied adaptive laboratory evolution (ALE) to three non-flocculent, industrial Saccharomyces cerevisiae brewer's strains using small continuous bioreactors (ministats) to obtain an aggregative phenotype, i.e., the "snowflake" phenotype. These aggregates could increase yeast sedimentation considerably. We evaluated the performance of these evolved strains and their produced flavor during lab scale beer fermentations. The small aggregates did not result in a premature sedimentation during the fermentation and did not result in major flavor changes of the produced beer. These results show that ALE could be used to increase the sedimentation behavior of non-flocculent brewer's strains.
\end{abstract}

Keywords: Saccharomyces cerevisiae; industrial brewer's strains; adaptive laboratory evolution (ALE); snowflake phenotype; beer fermentation

\section{Introduction}

Bulk sedimentation of yeast cells during fermentation is a crucial part of the brewing process. At the end of the fermentation, single yeast cells aggregate and form macroscopic "flocs" [1,2]. These clumps of cells then rapidly sediment from the beer and can be harvested from the bottom (lager fermentation) or float and can be harvested from the top (open ale fermentation) at the end of the primary fermentation. This phenomenon allows the brewer to separate the yeast from the beer in an effective, cost-efficient, and environmentally-friendly way, leaving only the clear and almost cell-free product. The neatly harvested yeast can also be "repitched" into the next fermentation. The timing of sedimentation is of considerable importance to the process. Sedimentation should not take place prematurely and cause stuck fermentation leading to beers with low quality flavor profiles. Complete sedimentation at the end of fermentation is preferred by the brewer, which provides the opportunity for a neat separation of the yeast cells from the beer [3].

Flocculation is the reversible, asexual self-adhesion of yeast cells which leads to their sedimentation [4]. Although single yeast cells do sediment, the large clumps formed by flocculating cells sediment at a 
much higher rate. The flocculation capacity of yeast is highly strain-dependent, influenced mainly by the genetic background since expressed cell wall flocculins that are lectins, effectuate cell-cell binding [5-7]. However, several environmental factors can affect flocculation too. Calcium availability, $\mathrm{pH}$, temperature, ethanol concentration and oxygen concentration are some of the physiological factors that influence flocculation while physical factors such as cell surface hydrophobicity and favorable hydrodynamic conditions can also affect formation of flocs [8-10]. The sedimentation rate is dependent on the size, shape and density of these flocs.

Optimization of the brewer yeast towards a more flocculating phenotype can lead to a more efficient beer production and a higher final beer quality. Recent advances in DNA sequencing, high-throughput technologies and genetic manipulation methods have led to the molecular and genomic characterization of the brewer's yeast. However, the exponential increase in knowledge generated in the field of functional genomics of yeast can only facilitate strain improvement efforts to some degree. Procedures to obtain approval for modified GMO yeasts are complicated and consumer acceptance for a GMO-produced beer is lacking [11,12]. These hurdles have guided researchers to look elsewhere to generate strains with desired properties.

One attractive more "natural" approach to enhance the attributes of microorganisms is the adaptive laboratory evolution (ALE) approach [13]. In ALE, microorganisms are cultivated under clearly defined conditions for long periods of time, allowing metabolic engineering of microorganisms utilizing genetic variation and selection for beneficial mutations $[14,15]$. Already a more-and-more used tool in microbial strain improvement, ALE has been applied for improving yeast strains such as for the utilization of alternative sugars by S. cerevisiae [16], increasing tolerance of S. cerevisiae to environmental conditions [17], for increasing the fermentation capacity of a lager S. pastorianus brewing strain under hyperosmotic conditions [18], modifying the production of flavor compounds by S. pastorianus for alcohol-free beer production [19], the adaptation of lager strains to very high-gravity brewing conditions [20,21], and for enhancing the fermentation rate with decreased formation of acetate and greater production of fermentative aroma of $S$. cerevisiae wine strains [22,23].

Microbial cells can be cultivated in parallel serial cultures for ALE but varying population densities, fluctuating growth rate, nutrient supply, and environmental conditions characterize this batch cultivation. Continuous (chemostat) cultures, however, ensure more stable conditions such as constant growth rate, tightly controlled nutrient supply and stable $\mathrm{pH}$ and oxygen availability [24-26].

Previously, we performed ALE of a S. cerevisiae strain in a 3D-printed continuous mini tower fermentor using gravity as a selective pressure to obtain a snowflake phenotype [27]. In this work, we've used the ALE approach for the continuous cultivation of three non-flocculating industrial S. cerevisiae brewing strains in miniature chemostats (ministats) [28]. This simple and low-cost setup was used to carry out adaptive evolution experiments where gravity is also the selective pressure on the planktonic cells, which are continuously removed while aggregating cells' sediment are retained. Stable aggregating cells were observed during continuous cultivation, showing a "snowflake" phenotype of unseparated daughter and mother cells. Finally, we have also demonstrated the beer fermentation performance of these evolved strains in lab scale tall tubes fermentors.

\section{Materials and Methods}

\subsection{Yeast Strains and Media}

The industrial Saccharomyces cerevisiae brewer's strains BCD1, BCD2, BCD3, and BCD4 were provided by Biercentrum Delvaux (Neerijse, Belgium). The lab strains BY4742 [29], BY4742 [FLO1], and BY4742::FLO8 [5] and the strong flocculating industrial strain BCD4 were used as control strains in the flocculation assay. All strains were precultured in YPD (Yeast extract-peptone-dextrose) medium $\left(1 \% \mathrm{~m} / v\right.$ yeast extract, $2 \% \mathrm{~m} / v$ peptone, $4 \% \mathrm{~m} / v$ glucose) overnight at $30^{\circ} \mathrm{C}$. For the continuous ALE in ministats, a high-glucose medium $\left(100 \mathrm{~g} / \mathrm{L}\right.$ D-glucose, $4 \mathrm{~g} / \mathrm{L}\left(\mathrm{NH}_{4}\right) \mathrm{SO}_{4}, 1.5 \mathrm{~g} / \mathrm{L} \mathrm{KH}_{2} \mathrm{PO}_{4}, 1 \mathrm{~g} / \mathrm{L}$ $\mathrm{MgSO}_{4} \cdot 7 \mathrm{H}_{2} \mathrm{O}$, and $5 \mathrm{~g} / \mathrm{L}$ yeast extract) was used. The yeast cells and aggregates were visualized by microscopy (Nikon Eclipse Ti2, Tokyo, Japan). 


\subsection{Flocculation Assay}

The assay described by D'Hautcourt and Smart [30] was used with minor modifications. Cells were cultivated for $24 \mathrm{~h}$ in YPD, harvested by centrifugation and resuspended in EDTA buffer $(50 \mathrm{mM}$ EDTA, $\mathrm{pH} 7$ ) to reach an $\mathrm{OD}_{600 \mathrm{~nm}}$ value of 10 . A sample of $50 \mu \mathrm{L}$ was taken at $0.5 \mathrm{~mL}$ below the meniscus, and the sample was diluted 20 times in a $1.5 \mathrm{~mL}$ cuvette with EDTA buffer (50 mM EDTA, $\mathrm{pH} 7$ ). The tubes were centrifuged ( $4000 \mathrm{rpm}, 3 \mathrm{~min}$ ), and the supernatant was discarded. The cells were resuspended in $1 \mathrm{~mL}$ flocculation buffer $\mathrm{A}\left(3 \mathrm{mM} \mathrm{CaSO}_{4}\right)$. The last step was repeated, but the cells were resuspended in flocculation buffer $\mathrm{B}\left(3 \mathrm{mM} \mathrm{CaSO}_{4}, 83 \mathrm{mM} \mathrm{CH}_{3} \mathrm{COONa}, 4 \%\right.$ v/v ethanol, $\left.\mathrm{pH} 4.5\right)$. The tubes were shaken at $100 \mathrm{rpm}$ for $10 \mathrm{~min}$. Prior to taking $50 \mu \mathrm{L}$ samples $0.5 \mathrm{~mL}$ below the meniscus, 3 min of sedimentation in a vertical position took place. The sample was diluted 20 times with EDTA buffer in a $1.5 \mathrm{~mL}$ cuvette. The absorbance of both suspensions in the cuvettes was determined, and the related flocculation percentage was calculated:

$$
\text { Flocculation percentage }(\%)=\frac{O D_{E D T A}-O D_{\text {Flocculation buffer }}}{O D_{E D T A}} \times 100
$$

For the evolved strains, $O D_{E D T A}$ corresponded to the $\mathrm{OD}_{600 \mathrm{~nm}}$ value of the non-evolved reference strain.

\subsection{Experimental Setup with Ministats}

The continuous fermentation of industrial strains was carried out in a ministat set-up (Figure S1) [28]. Briefly, $15 \mathrm{~mL}$ test tubes were kept in an analog heat block (VWR®, Bridgeport, NJ, USA) at $30^{\circ} \mathrm{C}$ and fed with high-glucose growth medium using a peristaltic pump (Type ISM833A, Ismatec $\AA$, Zurich, Switzerland). This high-glucose growth medium was previously also used in the adaptive evolution of S. cerevisiae strains towards a snowflake phenotype using a mini tower fermentor [27]. Medium was supplied at a flow rate of $30 \mu \mathrm{l} / \mathrm{min}$. Air from a 4-port aquarium pump was fed to the medium in the test tube through an air filter $(0.20 \mu \mathrm{m})$ and the needle was pushed to the bottom of the tube, in order to agitate the solution. During the experiment, a volume of 7-10 mL was maintained. The ministats were inoculated with $1 \mathrm{~mL}$ of an overnight culture. The $\mathrm{pH}$, cell concentration (OD at $600 \mathrm{~nm}$ ) and the glucose concentration (estimated using a refractometer (Brouwland, Belgium)) were measured during the ALE experiments.

\subsection{Wort Fermentations in Tall Tubes}

Laboratory-scale tall tubes, made from glass $(75 \mathrm{~cm}$ high and 8-cm diameter), were used to assess beer fermentation with the evolved strains (Figure S2a). The tall tubes were filled with $2 \mathrm{~L}$ of wort with a density of $11^{\circ} \mathrm{P}$, which was provided by Biercentrum Delvaux (Neerijse, Belgium), and autoclaved before inoculation. The evolved strains from the ALE experiment and the original brewer's strains $\mathrm{BCD} 1, \mathrm{BCD} 2$, and BCD3 were added to the tall tubes at a cell concentration of $10 \times 10^{6}$ cells $/ \mathrm{mL}$. Fermentations were carried out in duplicates and sampled daily.

Alcolyzer Plus Beer Analyzing System (Anton Paar®, Graz, Austria) and headspace gas chromatography (GC) (Autosystem XL, Perkin Elmer®, Waltham, MA, USA) were used for the analyses of the fermentation process. For the GC analysis, the samples were filtered through a filter paper (Grade MN $713 \frac{1}{4}$, Macherey-Nagel $\AA$, Düren, Germany). During the experiment, the apparent extract $(\% \mathrm{~m} / \mathrm{m})$ and the ethanol content $(\% v / v)$ were measured. The apparent extract $(\mathrm{Ea})$ is a direct measurement of the dissolved solids in brewer's wort, gauged according to specific gravity. During fermentation, the fermentable carbohydrates (glucose, maltose, and maltotriose) are consumed by the yeast and the progress of the fermentation is monitored by measuring the disappearance of these solids [31].

Concentrations of the volatile compounds (acetaldehyde, ethyl acetate, diacetyl, propanol, 2,3-pentanedione, isobutanol, isoamyl acetate (3-methyl-1-butylacetate), isoamyl alcohol (3-methyl- 
1-butanol), and ethyl caproate) in the beer samples were determined by headspace gas chromatography (HS-GC FID/ECD) as previously described [32,33]. Shortly, collected samples were cooled on ice and after centrifugation, $5 \mathrm{~mL}$ of the cooled supernatant was transferred to a vial. The vials were analyzed with a calibrated Autosystem XL gas chromatograph with a headspace autosampler (HS40; Perkin Elmer, Wellesley, MA, USA), equipped with a Chrompack-Wax 52 CB column (length $50 \mathrm{~m}, 0.32 \mathrm{~mm}$ internal diameter, $1.2 \mu \mathrm{m}$ layer thickness; Varian, Palo Alto, CA, USA). Samples were heated for $16 \mathrm{~min}$ at $60^{\circ} \mathrm{C}$ in the headspace autosampler before injection (needle temperature $70^{\circ} \mathrm{C}$ ). Helium was used as the carrier gas. The oven temperature was kept at $50{ }^{\circ} \mathrm{C}$ for $7.5 \mathrm{~min}$, increased to $110^{\circ} \mathrm{C}$ at $25^{\circ} \mathrm{C} / \mathrm{min}$, and was held at that temperature for $3.5 \mathrm{~min}$. Detection of esters, and higher alcohols was established with a flame ionization detector (FID); diacetyl was detected with an electron capture detector (ECD). The FID and ECD temperatures were kept constant at $250^{\circ} \mathrm{C}$ and $200^{\circ} \mathrm{C}$, respectively.

\section{Results}

\subsection{Adaptive Evolution in Ministats}

Adaptive evolution experiments were performed with the three selected non-flocculating industrial strains using continuous cultivation in the ministats. The flocculation behavior before evolution was assessed and compared to the non-flocculating haploid lab strain BY4742, the strongly flocculating BY4742 [FLO1] (constitutively overexpressed FLO1), the naturally flocculating BY4742::FLO8 (functional Flo8p) and the strongly flocculating industrial strain BCD4 (Figure 1a). The flocculation percentages of the three industrial strains were low $(<21 \% \pm 2 \%)$, ranking them below the natural flocculating BY4742::FLO8 reference lab strain (46\% $\pm 4 \%)$. The strongly flocculating industrial brewer's strain BCD4 shows the same flocculation capacity as the BY4742 lab strain with constitutively overexpressed FLO1.

For the ALE experiments, cultivation with the three strains was initiated with a dilution rate of approximately $0.2 \mathrm{~h}^{-1}$ using a medium feeding flow rate of $30 \mu \mathrm{L} / \mathrm{min}$. The cultivation was monitored daily by measuring the glucose concentration, $\mathrm{pH}$, and cell density (Figure 2). Between days 5-7, steady-state was reached and over time, and the dilution rate was increased gradually to $0.35 \mathrm{~h}^{-1}$ (BCD1) and $0.45 \mathrm{~h}^{-1}$ (BCD2, BCD3) to avoid wash-out and to select for larger aggregates. The continuous cultivation was stopped after 45 days, and the yeast populations were examined by microscopy (Figure 3). The evolved BCD2 aggregates were smaller than the BCD1 and BCD3 aggregates. The nature of the cell clusters was determined by resuspending the cells in EDTA-buffer, which chelates $\mathrm{Ca}^{+2}$ ions and disrupts yeast cell clusters if they are formed via flocculin-dependent adhesion. The aggregates persisted for all three strains. This indicated that the clusters are not the result of flocculin interactions and are likely due to failure in separation of the mother and daughter cells, described previously as the "snowflake" phenotype [27,34-36]. The evolved strains were subsequently cultivated in batch cultures and the aggregating phenotype was found to be stable.

The flocculation assay was repeated with the evolved strains to estimate and compare their sedimentation velocity to that of the BCD1, BCD2, and BCD3 strains before evolution (Figure 1). All three evolved strains showed an increase in "flocculation" percentage. Even though none of the strains evolved towards a real flocculating phenotype, their multicellular aggregates contributed to a significant larger sedimentation velocity. 
a

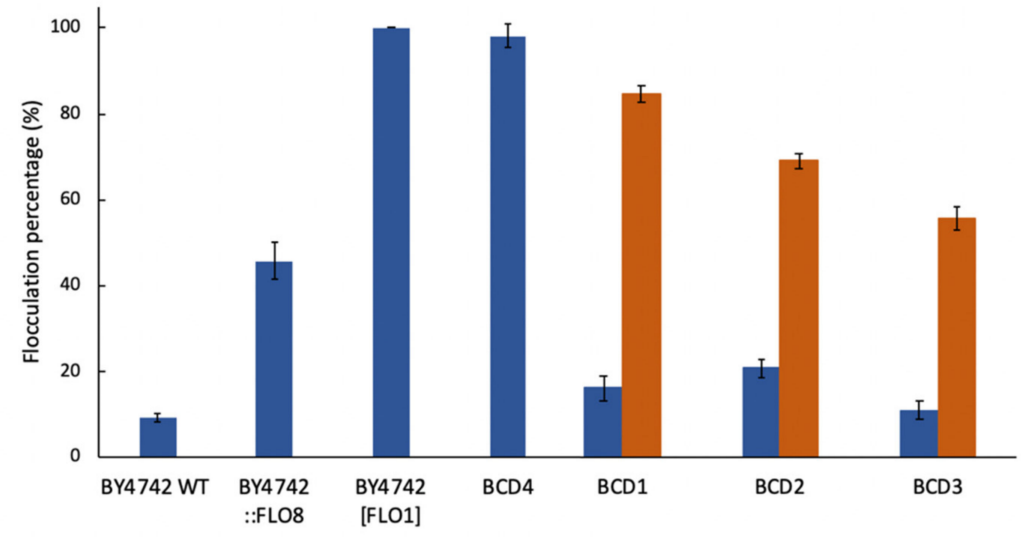

b

BCD1

BCD2

BCD3

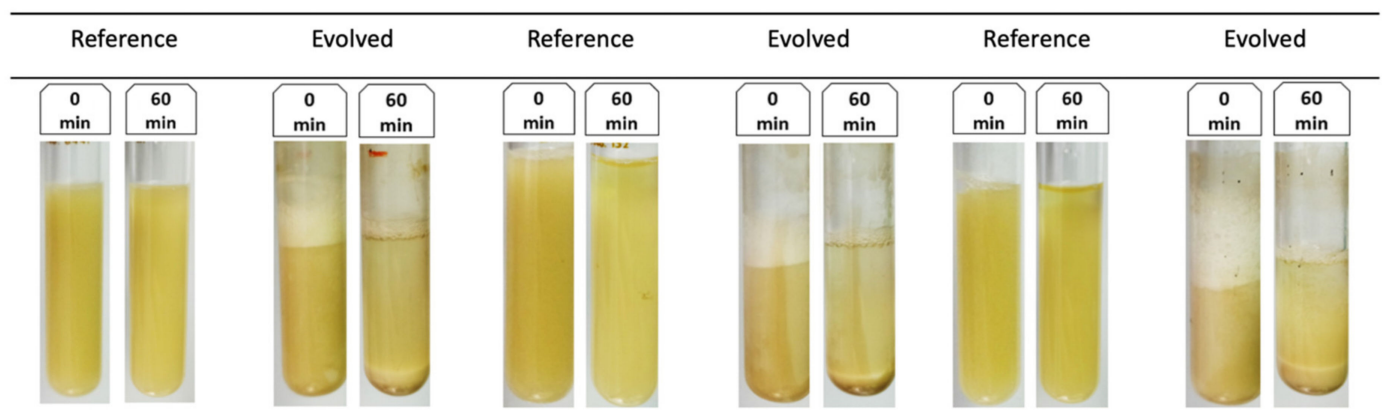

Figure 1. Flocculation and sedimentation behavior of laboratory and industrial strains. (a) Flocculation percentages determined for the control strains (BY4742, BY4742::FLO8, BY4742 (FLO1), the industrial BCD4 strain) and for the three industrial non-flocculating strains BCD1, BCD2, and BCD3 before ( $\square$ ) and after $(\square)$ ALE in ministats. All measurements were performed in triplicates. (b) The sedimentation behavior of the three industrial brewer's strains before and after adaptive laboratory evolution (ALE) in the ministats.
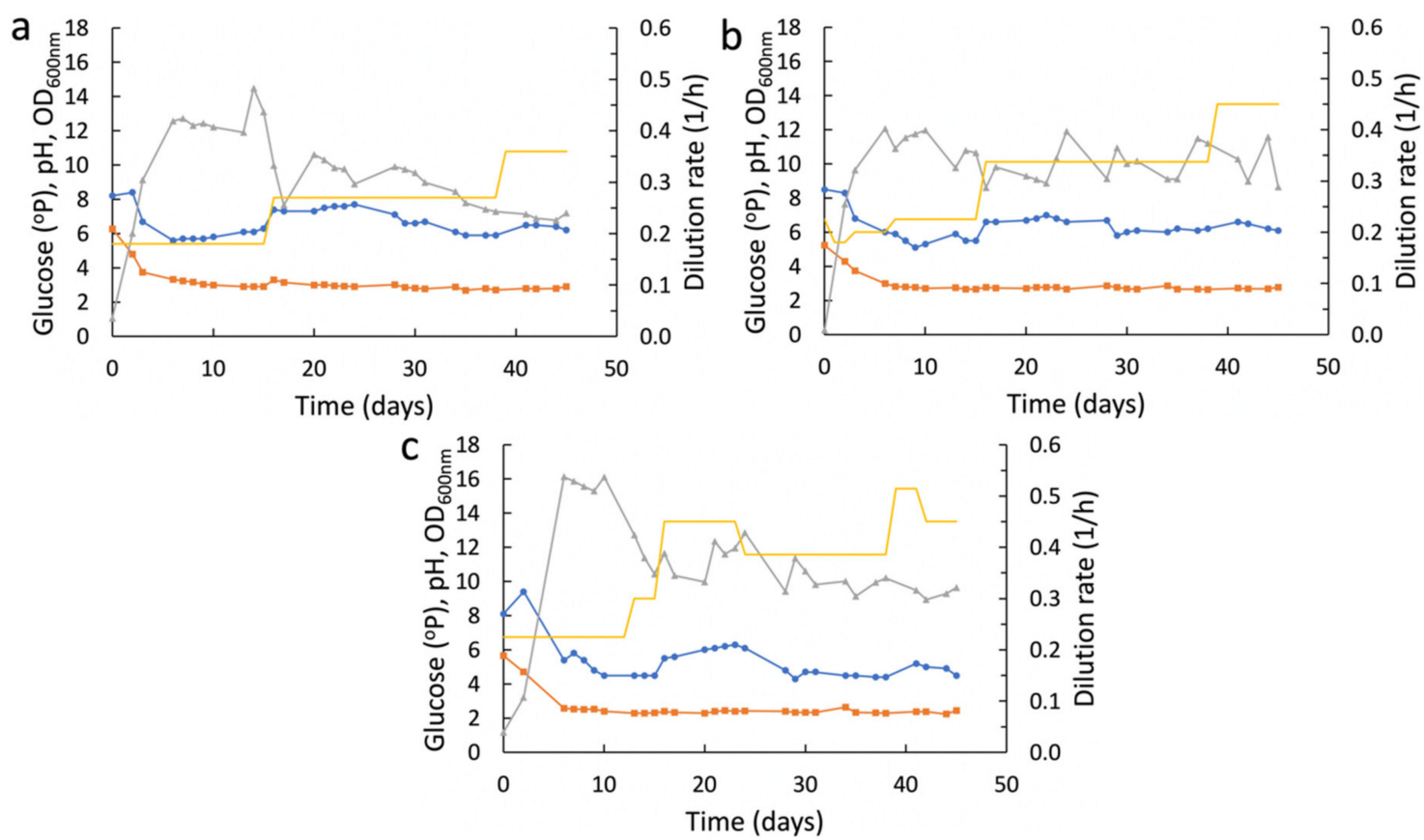

Figure 2. Cultivation of the industrial strains in the ministats: (a) BCD1, (b) BCD2, and (c) BCD3. Glucose content $(\bullet), \mathrm{pH}(\square), \mathrm{OD}_{600 \mathrm{~nm}}(\Delta)$, and the dilution rate $(1 / \mathrm{h})(-)$. 


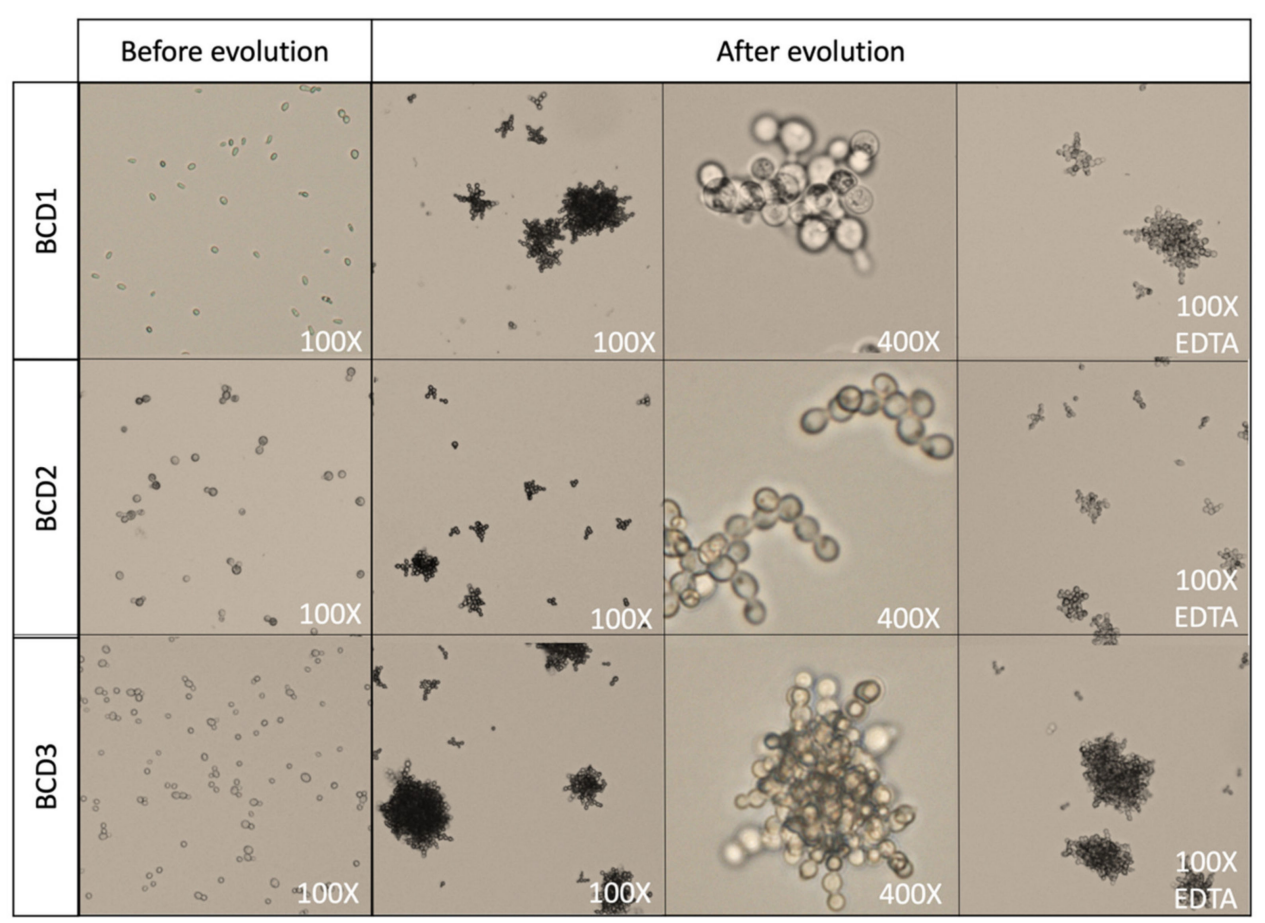

Figure 3. Microscopic observations of the industrial strains before and after the evolution in the ministats. Snowflake clumps are observed for each strain and could not be disrupted by treatment with $50 \mathrm{mM}$ EDTA.

\subsection{Performance of Evolved Strains During Beer Fermentation}

The performance and behavior of the evolved yeast strains, compared to their reference strains, were evaluated during wort fermentations in tall tubes (Figure S2a). The fermentations were monitored by sampling and measuring cell concentration and beer characteristics such as apparent extract $\left(E_{a}\right)$, ethanol content (Table S1), and the concentration of several flavor compounds (Figure S3 and S4).

The reference strain BCD1 showed a faster fermentation capacity than the evolved strain: The fermentation was almost completed after only 1 day as observed from the evolution of the apparent extract and ethanol concentration (Table S1) as well as from the suspended cell concentration (Figure S2b). The fermentation capacity of the evolved and reference BCD2 strains were similar (Table S1). In contrast, the evolved BCD3 strain showed a faster fermentation than the reference strain (Table S1). The evolution of the suspended cell concentrations during the fermentations for the evolved and reference strains is shown in Figure S1b. There are no large differences observable in the number of suspended cells between the evolved and the reference strains, except for the evolved BCD1 at the second day of fermentation where a much lower cell concentration of the evolved strain was present.

Flavor compounds in the beer were quantified by headspace gas chromatography (Figure S3 and S4). In general, no major influence of the evolved yeast strains on the development of the flavor profile was observed. Some remarkable observations include an increased content of vicinal diketones diacetyl (up to $2.1 \mathrm{ppm}$ ) and 2,3-pentanedione (up to $0.9 \mathrm{ppm}$ ) during the initial stages of the fermentation for the evolved BCD1 strain, which was decreased by the third day for both compounds to $0.1 \mathrm{ppm}$. Also, the aliphatic higher alcohol isobutanol concentration increased to $178 \mathrm{ppm}$ (compared to $53 \mathrm{ppm}$ for the reference strain) at the third day of the fermentation. The isobutanol concentration of the evolved $\mathrm{BCD} 2$ strain fermentation was doubled at the second day compared to the reference strain, but was still below the isobutanol flavor threshold of 100-200 ppm [37]. By the third day, the evolved BCD3 gave a lower concentration of acetaldehyde than its reference, but a higher concentration of the higher alcohol propanol and isobutanol, and the esters ethylacetate and isoamylacetate. 


\section{Discussion}

Miniature, low-cost chemostats (ministats) were used for adaptive laboratory evolution (ALE) of three industrial $S$. cerevisiae brewer's strains towards a more favorable, aggregating phenotype. The three strains-BCD1, BCD2, and BCD3 - were characterized with a low flocculation ability and were continuously cultivated with high-glucose medium for 45 days. Small clusters of cells were observed around day 15, corresponding to approximately 110 generations, which is comparable to other S. cerevisiae ALE experiments $[27,38,39]$. The yeast cell clusters were not disrupted by treatment by EDTA, which indicated that the cell-cell interactions are not based on flocculins. Microscopy showed that the multicellular clusters look like "snowflakes". This "snowflake" phenotype was previously described as the result of the failed separation of daughter cells from mother cells. This phenotype is caused by a frameshift mutation in the transcription factor ACE2, which is responsible for the activation of the CTS1 gene encoding the chitinase necessary to break down the septum between the mother and the daughter cells $[34,36,40]$. The clusters of cells formed in this way are unlike flocs in that they consist entirely of genetically identical cells and surrounding cells can not adhere to the cluster [36].

The performance of the evolved strains was compared to the reference strains in beer fermentations using tall tubes fermentors. During the fermentation only small aggregates of the evolved strains were observed. These aggregates were kept in suspension during the convective mixing by the $\mathrm{CO}_{2}$ release by the fermenting yeast cells as was clear from the evolution of the suspended cell concentration (Figure S2b). Apparently, shear stress by convective mixing will break up large aggregates and the presence of these small aggregates will not lead to premature sedimentation during fermentation. The $\mathrm{CO}_{2}$ production stops at the end of the fermentation and convective currents are reduced significantly. At this moment, the sedimentation of the snowflake aggregates will be significantly faster (Figure 1b) than the reference strains.

To assess the effect of adapted evolution of the 3 strains on the beer flavor, the evolution of a few flavor compounds was determined during the first 3 days of the fermentation. The evolved BCD1 strain showed an increased production of the vicinal diketones and the higher alcohol isobutanol. The synthesis of these compounds is linked to the isoleucine-leucine-valine (ILV) pathway. Although the flavor threshold of diacetyl (0.1-0.15 ppm [41]) was exceeded and the 2,3-pentanedione concentration was close to the flavor threshold (1.0-1.5 ppm [41]) during the first 2 days of fermentation, these concentrations were reduced significantly below the flavor threshold at the third day. Also, the isobutanol content in the beer fermented by the evolved BCD1 strain was much higher than for the reference strain, but did not exceed the flavor threshold of 100-200 ppm [37]. After 7 days, the green beer from the evolved and the reference BCD1 strain both tasted fruity (isoamyl acetate and acetaldehyde). Although the isobutanol concentration was larger in the beer from the evolved BCD2 strain, no difference was tasted. In both beers, the apple flavor (acetaldehyde) could be recognized. The beer from the evolved BCD3 strain contained a higher concentration of the ester isoamyl acetate (banana aroma) and ethyl acetate ester (fruity, solvent-like aroma), which presence could be tasted in the green beer.

Supplementary Materials: The following are available online at http://www.mdpi.com/2311-5637/6/1/20/s1, Figure S1: The experimental setup of the ministats. Figure S2: Beer fermentations in tall tube fermenters, Figure S3 and Figure S4: Comparison of the evolution of some flavor compounds during the tall tubes' fermentations; Table S1: Evolution of the apparent extract and ethanol content during the tall tube fermentations.

Author Contributions: Conceptualization, R.W. and F.R.D.; methodology, R.W., T.V.M.; formal analysis, T.V.M.; investigation, T.V.M., Y.K., F.D., F.R.D., and R.W..; resources, R.W.; writing-original draft preparation, Y.K., T.V.M.; writing-review and editing, Y.K., R.W., F.R., and F.R.D.; supervision, R.W., F.R.D., and F.D.; project administration, R.W.; funding acquisition, R.W. All authors have read and agree to the published version of the manuscript.

Funding: This research was funded by ESA-Belspo, grant PRODEX "Yeast Bioreactor".

Acknowledgments: The Belgian Federal Science Policy Office (Belspo) and the European Space Agency (ESA) PRODEX program supported this work. The Research Council of the Vrije Universiteit Brussel (Belgium) and the University of Ghent (Belgium) are acknowledged to support the Alliance Research Group VUB-UGent NanoMicrobiology (NAMI), and the International Joint Research Group (IJRG) VUB-EPFL BioNanotechnology \& NanoMedicine (NANO). 
Conflicts of Interest: The authors declare no conflict of interest.

\section{References}

1. Bowden, C.P.; Leaver, G.; Melling, J.; Norton, M.G.; Whittington, P.N. Recent and novel developments in the recovery of cells from fermentation broths. In Separations for Biotechnology; Verral, M.S., Hudson, M.J., Eds.; Ellis Horwood: Chichester, UK, 1987; pp. 49-61.

2. Stratford, M. Yeast flocculation: A new perspective. Adv. Microb. Physiol. 1992, 33, 1-71.

3. Vidgren, V.; Londesborough, J. 125th anniversary review: Yeast flocculation and sedimentation in brewing. J. Inst. Brew. 2011, 117, 475-487. [CrossRef]

4. Goossens, K.; Willaert, R. Flocculation protein structure and cell-cell adhesion mechanism in Saccharomyces cerevisiae. Biotechnol. Lett. 2010, 32, 1571-1585. [CrossRef]

5. Van Mulders, S.E.; Christianen, E.; Saerens, S.M.G.; Daenen, L.; Verbelen, P.J.; Willaert, R.; Verstrepen, K.J.; Delvaux, F.R. Phenotypic diversity of Flo protein family-mediated adhesion in Saccharomyces cerevisiae. FEMS Yeast Res. 2009, 9, 178-190. [CrossRef] [PubMed]

6. Willaert, R.G. Adhesins of yeasts: Protein structure and interactions. J. Fungi 2018, 4, 119. [CrossRef] [PubMed]

7. Brückner, S.; Mösch, H.-U. Choosing the right lifestyle: Adhesion and development in Saccharomyces cerevisiae. FEMS Microbiol. Rev. 2011, 36, 25-58. [CrossRef] [PubMed]

8. Verstrepen, K.J.; Derdelinckx, G.; Verachtert, H.; Delvaux, F.R. Yeast flocculation: What brewers should know. Appl. Microbiol. Biotechnol. 2003, 61, 197-205. [CrossRef] [PubMed]

9. Gibson, B.R.; Lawrence, S.J.; Leclaire, J.P.R.; Powell, C.D.; Smart, K.A. Yeast Responses to Stresses Associated with Industrial Brewery Handling. FEMS Microbiol. Rev. 2007, 31, 535-569. [CrossRef]

10. Soares, E.V. Flocculation in Saccharomyces cerevisiae: A review. J. Appl. Microbiol. 2010, 110, 1-18. [CrossRef]

11. Dequin, S. The potential of genetic engineering for improving brewing, wine-making and baking yeasts. Appl. Microbiol. Biotechnol. 2001, 56, 577-588. [CrossRef]

12. Saerens, S.M.G.; Duong, C.T.; Nevoigt, E. Genetic improvement of brewer's yeast: Current state, perspectives and limits. Appl. Microbiol. Biotechnol. 2010, 86, 1195-1212. [CrossRef] [PubMed]

13. Conrad, T.M.; Lewis, N.E.; Palsson, B.Ø. Microbial laboratory evolution in the era of genome-scale science. Mol. Syst. Biol. 2011, 7, 509. [CrossRef] [PubMed]

14. Portnoy, V.A.; Bezdan, D.; Zengler, K. Adaptive laboratory evolution-harnessing the power of biology for metabolic engineering. Curr. Opin. Biotechnol. 2011, 22, 590-594. [CrossRef] [PubMed]

15. Dragosits, M.; Mattanovich, D. Adaptive laboratory evolution-Principles and applications for biotechnology. Microb. Cell Fact. 2013, 12, 64. [CrossRef]

16. Sonderegger, M.; Sauer, U. Evolutionary engineering of Saccharomyces cerevisiae for anaerobic growth on xylose. Appl. Environ. Microbiol. 2003, 69, 1990-1998. [CrossRef]

17. Dhar, R.; Sägesser, R.; Weikert, C.; Wagner, A. Yeast adapts to a changing stressful environment by evolving cross-protection and anticipatory gene regulation. Mol. Biol. Evol. 2013, 30, 573-588. [CrossRef]

18. Ekberg, J.; Rautio, J.; Mattinen, L.; Vidgren, V.; Londesborough, J.; Gibson, B.R. Adaptive evolution of the lager brewing yeast Saccharomyces pastorianus for improved growth under hyperosmotic conditions and its influence on fermentation performance. FEMS Yeast Res. 2013, 13, 335-349. [CrossRef]

19. Strejc, J.; Siřiššt'ová, L.; Karabín, M.; Almeida e Silva, J.B.; Brányik, T. Production of alcohol-free beer with elevated amounts of flavouring compounds using lager yeast mutants. J. Inst. Brew. 2013, 119, 149-155. [CrossRef]

20. Huuskonen, A.; Markkula, T.; Vidgren, V.; Lima, L.; Mulder, L.; Geurts, W.; Walsh, M.; Londesborough, J. Selection from Industrial Lager Yeast Strains of Variants with Improved Fermentation Performance in Very-High-Gravity Worts. Appl. Environ. Microbiol. 2010, 76, 1563-1573. [CrossRef]

21. Yu, Z.; Zhao, H.; Li, H.; Zhang, Q.; Lei, H.; Zhao, M. Selection of Saccharomyces pastorianus variants with improved fermentation performance under very high gravity wort conditions. Biotechnol. Lett. 2012, 34, 365-370. [CrossRef]

22. Cadière, A.; Ortiz-Julien, A.; Camarasa, C.; Dequin, S. Evolutionary engineered Saccharomyces cerevisiae wine yeast strains with increased in vivo flux through the pentose phosphate pathway. Metab. Eng. 2011, 13, 263-271. [CrossRef] [PubMed] 
23. Cadière, A.; Aguera, E.; Caillé, S.; Ortiz-Julien, A.; Dequin, S. Pilot-scale evaluation the enological traits of a novel, aromatic wine yeast strain obtained by adaptive evolution. Food Microbiol. 2012, 32, 332-337. [CrossRef] [PubMed]

24. Weikert, C.; Sauer, U.; Bailey, J.E. Use of a glycerol-limited, long-term chemostat for isolation of Escherichia coli mutants with improved physiological properties. Microbiology 1997, 143, 1567-1574. [CrossRef] [PubMed]

25. Koppram, R.; Albers, E.; Olsson, L. Evolutionary engineering strategies to enhance tolerance of xylose utilizing recombinant yeast to inhibitors derived from spruce biomass. Biotechnol. Biofuels 2012, 5, 32. [CrossRef] [PubMed]

26. Wang, L.; Spira, B.; Zhou, Z.; Feng, L.; Maharjan, R.P.; Li, X.; Li, F.; McKenzie, C.; Reeves, P.R.; Ferenci, T. Divergence involving global regulatory gene mutations in an Escherichia coli population evolving under phosphate limitation. Genome Biol. Evol. 2010, 2, 478-487. [CrossRef]

27. Conjaerts, A.; Willaert, R. Gravity-Driven Adaptive Evolution of an Industrial Brewer's Yeast Strain towards a Snowflake Phenotype in a 3D-Printed Mini Tower Fermentor. Fermentation 2017, 3, 4. [CrossRef]

28. Miller, A.W.; Befort, C.; Kerr, E.O.; Dunham, M.J. Design and use of multiplexed chemostat arrays. J. Vis. Exp. 2013, e50262. [CrossRef]

29. Brachmann, C.B.; Davies, A.; Cost, G.J.; Caputo, E.; Li, J.; Hieter, P.; Boeke, J.D. Designer Deletion Strains derived from Saccharomyces cerevisiae S288C: A Useful set of Strains and Plasmids for PCR-mediated Gene Disruption and Other Applications. Yeast 1998, 14, 115-132. [CrossRef]

30. D'Hautcourt, O.; Smart, K.A. Measurement of brewing yeast flocculation. J. Am. Soc. Brew. Chem. 1999, 57, 123-128. [CrossRef]

31. Shimizu, H.; Mizuno, S.; Hiroshima, T.; Shioya, S. Effect of carbon and nitrogen additions on consumption activity of apparent extract of yeast cells in a brewing process. J. Am. Soc. Brew. Chem. 2002, 60, 163-169. [CrossRef]

32. Verbelen, P.J.; Dekoninck, T.M.L.; Saerens, S.M.G.; Van Mulders, S.E.; Thevelein, J.M.; Delvaux, F.R. Impact of pitching rate on yeast fermentation performance and beer flavour. Appl. Microbiol. Biotechnol. 2009, 82, 155-167. [CrossRef] [PubMed]

33. Dekoninck, T.M.L.; Mertens, T.; Delvaux, F.; Delvaux, F.R. Influence of beer characteristics on yeast refermentation performance during bottle conditioning of belgian beers. J. Am. Soc. Brew. Chem. 2013, 71, 23-34. [CrossRef]

34. Ratcliff, W.C.; Fankhauser, J.D.; Rogers, D.W.; Greig, D.; Travisano, M. Origins of multicellular evolvability in snowflake yeast. Nat. Commun. 2015, 6, 6102. [CrossRef] [PubMed]

35. Ratcliff, W.C.; Denison, R.F.; Borrello, M.; Travisano, M. Experimental evolution of multicellularity. Proc. Natl. Acad. Sci. USA 2012, 109, 1595-1600. [CrossRef]

36. Oud, B.; Guadalupe-Medina, V.; Nijkamp, J.F.; De Ridder, D.; Pronk, J.T.; Van Maris, A.J.A.; Daran, J.M. Genome duplication and mutations in ACE2 cause multicellular, fast-sedimenting phenotypes in evolved Saccharomyces cerevisiae. Proc. Natl. Acad. Sci. USA 2013, 110, E4223-E4231. [CrossRef]

37. Djordjević, V.; Willaert, R.; Gibson, B.; Nedović, V. Immobilized Yeast Cells and Secondary Metabolites. In Fungal Metabolites; Springer International Publishing: Berlin/Heidelberg, Germany, 2016; pp. 1-40.

38. Ratcliff, W.C.; Pentz, J.T.; Travisano, M. Tempo and mode of multicellular adaptation in experimentally evolved Saccharomyces cerevisiae. Evolution 2013, 67, 1573-1581. [CrossRef]

39. Hope, E.A.; Amorosi, C.J.; Miller, A.W.; Dang, K.; Heil, C.S.; Dunham, M.J. Experimental evolution reveals favored adaptive routes to cell aggregation in yeast. Genetics 2017, 206, 1153-1167. [CrossRef]

40. King, L.; Butler, G. Ace2p, a regulator of CTS1 (chitinase) expression, affects pseudohyphal production in Saccharomyces cerevisiae. Curr. Genet. 1998, 34, 183-191. [CrossRef]

41. Meilgaard, M.C. Flavor chemistry of beer: Part ii: Flavour and threshold of 239 aroma volatiles. MBAA Tech. Q. 1975, 12, 151-168.

(C) 2020 by the authors. Licensee MDPI, Basel, Switzerland. This article is an open access article distributed under the terms and conditions of the Creative Commons Attribution (CC BY) license (http://creativecommons.org/licenses/by/4.0/). 